Kevin Aquilina ${ }^{1}$

University of Malta

\title{
Church and State Relations in the Constitution of Malta
}

The Constitution of Malta (hereinafter 'the Constitution'), the highest law of the land, regulates the relationship between the Catholic Church and the State of Malta. This is because there are a number of provisions in the Constitution which refer to the Roman Catholic Apostolic Church and to religion as discussed below. First, there is the provision which includes the Catholic religion amongst the state's symbols. Then there is the provision which regulates the teaching of religion in state schools. Finally, there are provisions in the Constitution which deal with freedom of conscience and worship. It is understandable that the Constitution contains such provisions on the Church and on religion because Malta is a Catholic country. However, this paper recounts, from a historic and legal perspective, that recent secularisation trends are eroding the special status that the Church and the Catholic religion have enjoyed in Maltese society and, the more time passes, it appears that Malta is moving in the footsteps of Western Europe of losing its religious character to substitute it with a more secular outlook. This is evident from the legislation surveyed in this paper which tends to inspire itself less for the making

1 Professor Kevin Aquilina is the Dean of the Faculty of Laws at the University of Malta. E-mail: kevin.aquilina@um.edu.mt. 
of legislation from the Catholic values perspective previously cherished by the Maltese.

\section{The National Religion in the Constitution of Malta}

Chapter $\mathrm{I}^{2}$ of the Constitution of Malta is entitled The State. It sets out Malta's territories and state symbols, comprising the Roman Catholic Apostolic Religion as the State religion, the national flag of Malta, including a representation thereon of the George Cross awarded to Malta by His Majesty King George the Sixth on the 15 April 1942, the national anthem, the national language being the Maltese language and the supremacy provision of the Constitution.

\subsection{A Confessional State}

The Constitution is confessional because one of the state symbols it establishes, in its very opening chapter, is the state religion. It declares that 'the religion of Malta is the Roman Catholic Apostolic Religion'. ${ }^{3}$ It recognises that 'the authorities of the Roman Catholic Apostolic Church have the duty and the right to teach which principles are right and which are wrong' $^{4}$ and mandates that religious teaching 'of the Roman Catholic

2 Constitution of Malta, sections 1 to 6.

3 Constitution, section 2(1). Ian Refalo opines that the Constitution 'is confessional insofar as it confesses the Roman Catholic religion to be its faith. This is a statement which is reflective of a deep Maltese cultural tradition, and serves to underline the Maltese character of our constitution. Some may argue that in a constitution which preached non-discrimination this is out of place; I would not believe so - an admission of belonging and an affirmation of a cultural identity as long as such affirmations are kept in proper check and are not allowed to overflow into divisiveness is healthy and proper. Indeed, a constitution is not made solely of rules, laws and political usages, it is also made of symbols which permit to foster common identity and the sense of people; such are the references to the Maltese language and to the Maltese flag. Also they play a role in the making of a constitution and in the securing of a common identity and a common allegiance'. I. Refalo, Constitutional Change in Malta', in: Office of the President, The President's Forum: Does Malta's Constitution Still Cater for the People's Needs, Valletta, p. 74.

4 Constitution, section 2(2). 
Apostolic Faith shall be provided in all State Schools as part of compulsory education'. ${ }^{5}$ The Constitution, however, was not the first law to contain the declaration that the Catholic religion is the religion of Malta. ${ }^{6}$ Indeed, through the Religion of Malta (Declaration) Act, the bicameral legislature of colonial Malta enacted a law to declare that the Roman Catholic Apostolic Religion is the religion of Malta and its dependencies on the following lines:

WHEREAS the Roman Catholic Apostolic Religion is, and has always been, the Religion of the people of Malta and its Dependencies;

AND WHEREAS a declaration to that effect has already been made by the Senate and the Legislative Assembly at their joint meeting held on the third November, 1921;

AND WHEREAS it is necessary to give more formal sanction to this declaration; ... The Roman Catholic Apostolic Religion is, as it has always been in the past, the Religion of Malta and its Dependencies. ${ }^{8}$

The draft of the Constitution approved by the National Assembly at the sitting of 8 August 1919 had the following as its very first section: 'The religion of Malta and its Dependencies is the Roman Catholic Apostolic Faith'.

5 Constitution, section 2(3).

6 For the historical evolution of the Roman Catholic Apostolic Religion from 1798 to 1975 , see A. Bonnici, History of the Church in Malta, Vol. 3, Period 4 -1800-1975, Zabbar 1975, pp. 179-188.

7 Enacted by Act No I of 1922 on 4 March 1922, Chapter 79 of the Laws of Malta. See D. Micallef, 1921: Electoral Issues, "Hyphen - A Journal published by the Lyceum" Vol. II, No. 4, 1980, at pp. 159-160 and 1921 A Landmark in Maltese Political History, Msida 1978, pp. 47-48.

8 For a discussion on the Religion of Malta (Declaration) Act 1922 and the historical circumstances leading to its enactment, see Ch. J. Scicluna, Religion and the 1921 Constitution: Genesis and Implications, Licentiate in Sacred Theology, Faculty of Theology, University of Malta, Rabat, October 1988, in particular pp. 129-145; and R. Mangion, Aspects on forces of influence by persons and groups under Malta's first responsible government, in: The Quest for Authenticity and Human Dignity, Melita Theologica, eds. E. Agius, H. Scerri, Msida 2015, at pp. 308-310 (Supplementary Series, 6).

9 See House of Commons Parliamentary Papers, Papers Relating to the New Constitution of Malta, His Majesty's Stationery Office, London 1921 [1921], Cmd. 1321, p. 6. Section 163 of the Criminal Code is discussed by J. A. Herrera, Crimes Against the Religious Sentiment, LL.D. thesis, Faculty of Laws, University of Malta, Msida 1958. 
When the independence Constitution came into force, the above enactment was strictly speaking rendered superfluous so much so that it was subsequently repealed by the Laws (Amendment and Repeal) (No. 2) Act, 1982, ${ }^{10}$ an Act to amend or repeal certain laws. Section 2 was deeply entrenched by the 1964 Constitution as its amendment required both the support of at least a two-thirds majority vote of the members of the House of Representatives and a majority vote in a constitutional amendment referendum. But, in terms of the 1974 constitutional amendments, the declaration per se has no longer been entrenched by section $66(2)(b)$ of the Constitution but only the second subsection thereof has been entrenched so that whilst strictly speaking the declaration can be repealed by an absolute majority vote in the House of Representatives (as is also the case with section 2(3)), the same cannot be said with regard to the Roman Catholic Apostolic Church's duty and right 'to teach which principles are right and which are wrong' which requires at least a twothirds majority vote of the Members of the House.

\subsection{Vilification of Religion}

To give concrete effect to the 1922 declaration, the Criminal Code was amended in 1933 where a new Title IV was added to Part II of Book First of the Criminal Code entitled of Crimes Against the Religious Sentiment. Section 163 specifically criminalised the vilification of "the Roman Catholic Apostolic Religion which is the religion of Malta"11 whilst section 164 criminalised vilification of other cults tolerated by law. Nonetheless, although Malta is a confessional state, it is not a theocracy. This is because other cults can be freely professed in Malta and freedom of conscience and worship are guaranteed both by the Constitution and the European Convention on Human Rights. The distinction between a theocracy and a confessional state lies very much in the fact that although a confessional state has its own state religion, it admits freedom

10 Act No. XVI of 1982.

11 Criminal Code, section 163. 
of religion and the liberty to profess other cults freely and unhindered whilst a theocracy does not.

Bill 113 of 2015, the Criminal Code (Amendment) Bill of 2015, proposed - in clause 2 - the deletion of the two provisions in the Criminal Code establishing the crime of vilification, the first (section 163) of the Roman Catholic Apostolic Religion and the second (section 164) of other cults. From a legislative drafting style viewpoint, it made sense to declare the Catholic Religion as the official religion of Malta in one enactment - Religion of Malta (Declaration) Act - and to establish its vilification in another law (the Criminal Code) bearing in mind that the Criminal Code is a codified compilation of crimes and contraventions and hence it is more appropriate to insert the penal provision, as opposed to the constitutional provision, in the Criminal Code rather than in the constitutional enactment. The same legislative drafting pattern was retained by the Constitution (which, after all, is not a penal enactment) not only with regard to the national religion but also with regard to other national symbols of the State such as the National Flag and the George Cross Award.

The State of Malta is a confessional state because it is the Constitution which clearly and unequivocally proclaims it to be so even though such declaration does not prejudice the profession of other cults which, nonetheless, are still protected both through the freedom of conscience and worship provision in section 40 of the Constitution and, prior to 2016, trough section 164 of the Criminal Code prohibiting the vilification of cults (other than the Roman Catholic Apostolic Religion) and all this apart from Article 9 of the European Convention on Human Rights and its Protocols. Being confessional simply means that the Constitution is giving recognition to a determinate religion - the Roman Catholic Apostolic Religion - over all other religions, as being the sole and official religion of the state. But, in doing so, it does not suppress the profession of other cults which are tolerated by law. Although the vilification provisions in the Criminal Code have been adopted from the Italian Codice Penale ${ }^{12}$

12 Translation: Criminal Code. 
of 1889 , Italy ${ }^{13}$ has on 24 February 2006 made changes to its Criminal Code which, nevertheless, were not taken on board in Malta as the Maltese Government, instead, advocated their repeal through Bill 113 of 2015 which was subsequently enacted into law as the Criminal Code (Amendment) Act, 2016, Act No. XXXVII of 2016. ${ }^{14}$ It is this enactment which has left the state symbol of religion denuded of any protection at law as was hitherto the position under the vilification of religion section 163 provision in the Criminal Code.

\subsection{Compulsory Teaching of Religion in State Schools}

The provision in the Constitution related to the compulsory teaching of religion in state schools is supplemented by section 47(3) of the Education Act. ${ }^{15}$ The Constitution further provides in section 45(9) - related to the protection from discrimination - that: 'A requirement, however made, that the Roman Catholic Apostolic Religion shall be taught by a person professing that religion shall not be held to be inconsistent with or in contravention of this article'. On the other hand, section 40 when dealing with the protection of freedom of conscience and worship, provides that although "no person shall be required to receive instruction in religion or to show knowledge or proficiency in religion', such requirement does not preclude its application in the case where 'the knowledge of, or proficiency or instruction in, religion is required for the teaching of such religion, or for admission to the priesthood or to a religious order, or for other religious purposes, and except so far as that

13 See F. Basile, A Cinque Anni della riforma dei reati in materia di religione: un commento teorico-pratico degli artt. 403, 404 e 405 c.p. (Translation: Five Years from the reform of religious crimes: a theoretical-practical commentary on sections 403, 404 and 405 of the Criminal Code), Stato, Chiesa e pluralismo confessionale (Translation: State, Church and Confessional Pluralism), May 2011, available at: www.statochiesa.it. Last accessed on 28 November 2017.

${ }_{14}$ See K. Aquilina, Religion needs protection, "The Times of Malta" 22 July, 2015, p. 22; Guardian of the Constitution, "The Times of Malta" 28 September 2015, p. 16; Retain vilification law, "The Times of Malta" 6 October 2015, p. 14; Archdiocese of Malta, Position paper on the Decriminalisation of the Public Vilification of Religion and Pornography, Conferentia Episcopalis Meliensis, "Floriana" 7 August 2015, pp. 1-45.

15 Chapter 327 of the Laws of Malta. 
requirement is shown not to be reasonably justifiable in a democratic society'. ${ }^{16}$

On a different note, in terms of the Ecclesiastical Offices or Benefices (Appointment by Foreign Power) Ordinance ${ }^{17}$ the appointment of Archbishop of Malta by the Pope was invalid 'until it is approved by the Prime Minister', ${ }^{18}$ and the same provision was extended to the Bishop of Gozo in terms of the Bishop of Gozo (Extension of Privileges) Ordinance. ${ }^{19}$ However, both Ordinances were recently repealed by the Laws (Amendment and Repeal) Act, 2015. ${ }^{20}$

\subsection{Protection of Freedom of Conscience and Worship}

Freedom of conscience and worship are regulated by section 40 of the Maltese Constitution where it is stated that all "persons in Malta shall have full freedom of conscience and enjoy the free exercise of their respective mode of religious worship. ${ }^{21}$ That said, however, the Constitution limits the exercise of this freedom in the case of a law that 'makes provision that is reasonably required in the interests of public safety, public order, public morality or decency, public health, or the protection of the rights and freedoms of others, and except so far as that provision or, as the case may be, the thing done under the authority thereof, is shown not to be reasonably justifiable in a democratic society'.22

In addition, no person is 'required to receive instruction in religion or to show knowledge or proficiency in religion if, in the case of a person

16 Constitution, section 40(2) proviso. For a history and development of church-state relations during the British period, see G. E. DeGiorgio, Church and State in Malta, "Scientia" Vol.14, Apr.-Jun. 1948, pp. 57-66 and Vol.14,Jul.-Sept. 1948, pp. 128-143; and Sir A. Mercieca, Stato e Chiesa in Malta: Nomina dei Vescovi, "Archivio Storico di Malta" Vol. 7, 1935-1936, pp. 87-92.

17 Chapter 6 of the Laws of Malta. This Ordinance dated back to 13 January 1838.

18 Ecclesiastical Offices or Benefices (Appointment by Foreign Power) Ordinance, section 2.

19 Chapter 15 of the Laws of Malta, section 4. This Ordinance dated back to 30 June 1865.

20 Act No. II of 2015.

21 Constitution, section 40(1).

22 Constitution, section $40(3)$. 
who has not attained the age of sixteen years, objection to such requirement is made by the person who according to law has authority over him and, in any other case, if the person so required objects thereto'. But such requirement is not inconsistent with or in contravention of freedom of conscience and worship to the extent that the knowledge of, or the proficiency or instruction in, religion is required for the teaching of such religion, or for admission to the priesthood or to a religious order, or for other religious purposes, and except so far as that requirement is shown not to be reasonably justifiable in a democratic society'. ${ }^{23}$

\section{Religious Denominational Equality}

In so far as protection of conscience and worship is concerned, the Constitution safeguards the freedom of all persons in Malta to enjoy 'full freedom of conscience' and 'the free exercise of their respective mode of religious worship'. ${ }^{24}$ The latter words are indicative of the fact that, although Malta is predominantly a Roman Catholic country, it still guarantees other religious denominations the right to worship according to non-Catholic religious rites and traditions. In this respect, freedom of cult is practiced and applied indiscriminately.

\subsection{Canon Law Influence on the legal relationship between Church and State}

Canon Law is not just simply the law of the Roman Catholic Apostolic Church which has been an influencing factor on Malta surely from the time of the Order of St. John onwards, if not from the time of the advent of St. Paul in the Maltese islands. ${ }^{25}$ As Robinson, Fergus and Gordon hold, 'canon law was more than a collection of technical rules; it was a force

${ }^{23}$ Constitution, section 40(2).

24 Constitution, section 1(1).

25 Circa 61 A.D. Acts of the Apostles, 28: 1-10 in Anon, The Jerusalem Bible, London, pp. 246-247. 
which shaped all society, lay and cleric alike; their membership of society made them members of the Church and subject to the rational ordering of a daily life that was seen sub specie aeternitatis'. ${ }^{26}$

\subsection{The Influence of Canon Law on the Constitution}

The suprema lex of the land - the Constitution - is influenced by the 1917 Code of Canon Law. The Constitution proclaims that the 'religion of Malta is the Roman Catholic Apostolic Religion'. ${ }^{27}$ The implication of this declaration in the Constitution in so far as State-Church relations are concerned is that the 'authorities of the Roman Catholic Apostolic Church have the duty and the right to teach which principles are right and which are wrong'. ${ }^{28}$ Furthermore, religious teaching 'of the Roman Catholic Apostolic Faith shall be provided in all State schools as part of compulsory education' ${ }^{29}$ The Catholic religion is not only the state adopted religion but even the Catholic Church is recognised by the

26 O. F. Robinson, T. D. Fergus and W. M. Gordon, European Legal History, second edition, London 1994, p. 72.

27 Constitution, section 2(1).

28 Constitution, section 2(2): this provision was added to the Constitution in 1974 by section 4 of Act No. LVIII of 1974, through which enactment Malta became a Republic. Canon 1322 of the 1917 Code of Canon Law dealt with 'The Power to Teach'. It provided that: 'Our Lord Jesus Christ entrusted the deposit of faith to the Church, that under the constant guidance and assistance of the Holy Spirit, she might sacredly guard and faithfully explain this divine revelation. The Church has therefore the right and the duty, independently of any civil power, to teach all nations the full evangelical doctrine, and all men are bound by the law of God to learn this doctrine properly and to embrace the true Church of God'. See T. L. Bouscaren, A. C. Ellis, Canon Law: A Text and Commentary (third revised edition, Milwaukee 1957, p. 723. A more developed version of this canon is found in canon 747 of the Code of Canon Law of 1983. See New Commentary on the Code of Canon Law, eds. J. P. Beal, J. A. Coriden, Th. J. Green, New York 2000, pp. 911-912.

29 Constitution, section 2(3); Canon 1113 of the Code of Canon Law of 1917 provided that: 'Parents are bound by a most serious obligation to provide to the best of their power for the religious and moral as well as for the physical and civil education of their children, and also to provide for their temporal welfare'. See T. L. Bouscaren, A. C. Ellis, Canon Law: A Text and Commentary, op. cit., note 421, p. 583. The Code of Canon Law of 1983, in canon 226, paragraph 2, has got a similar provision when it provides that: 'Since they have given life to their children, parents have a most grave obligation and possess the right to educate them. Therefore, it is for Christian parents particularly to take care of the Christian 
Constitution and the Catholic faith has to be thought as part of compulsory education in state schools. No such treatment is afforded in the Constitution to any other religion. Furthermore, section 45(9) provides that a 'requirement, however made, that the Roman Catholic Apostolic Religion shall be taught by a person professing that religion shall not be held to be inconsistent with or in contravention of this section'. Linked to this latter provision is section 40 dealing with the protection of freedom of conscience and worship which, in section $40(2)$, provides that:

\begin{abstract}
No person shall be required to receive instruction in religion or to show knowledge or proficiency in religion if, in the case of a person who has not attained the age of sixteen years, objection to such requirement is made by the person who according to law has authority over him and, in any other case, if the person so required objects thereto: provided that no such requirement shall be held to be inconsistent with or in contravention of this article to the extent that the knowledge of, or proficiency or instruction in, religion is required for the teaching of such religion, or for admission to the priesthood or to a religious order, or for other religious purposes, and except so far as that requirement is shown to be reasonably justifiable in a democratic society.
\end{abstract}

\title{
3.3. Ordinary Laws
}

The legal relationship between Church and State is contained in various laws some written others not. For instance, the order of precedence which is accorded to His Grace the Archbishop and the Bishop of Gozo as well as the Auxiliary Bishop is not written down in a law but in a policy document adopted by the Ministry of Foreign Affairs. The ecclesiastical authorities are dignitaries who are given their respect by being placed nearly at the very beginning of the order of precedence. Other non-written instances when the Church and State come into contact is when at the beginning of each sitting of the House of Representatives the Speaker recites 'The Lord's Prayer', 'Hail, Mary' and 'Glory be to the Father' and other government institutions such as the Broadcasting Authority, the University Senate, etc., open their meeting with a prayer. The church

education of their children according to the doctrine handed on by the Church'. See New Commentary on the Code of Canon Law, op. cit., supra, note 421, pp. 293-295. 
is also called upon to officiate in various state activities which take place at St John's Co-Cathedral, Valletta, as well as in blessing new government premises, local council premises, animals, agricultural products, etc. The Archbishop also delivers a message before the New Year and receives at the Archbishop's Palace in Valletta the highest civil authorities in Malta - Prime Ministers, Ministers, Members of Parliament, the Opposition, the judiciary, etc. on New Year's Day. State institutions such as schools, court halls, offices and hospitals are adorned by a crucifix. These are vestiges of tradition in the light of the fact that the Maltese have been predominantly a Catholic country.

The same approach is adopted by the Education $\mathrm{Act}^{30}$ which provides in section 47(3) that: 'It shall be the duty of the Minister to provide for the education and teaching of the catholic religion in State schools and to establish the curriculum for the education and teaching of that religion in those schools according to the dispositions in this regard of the Bishops in Ordinary of these Islands ${ }^{31}$ and, further, in section $47(5)$, that a minor's parents have the right to opt that such minor may not receive Catholic instruction. ${ }^{32}$ Non-Catholic religions are not considered at a par with the Catholic religion as these are not taught in school. Finally, the Education Act contains a provision regulating the Faculty of Theology

30 Chapter 237 of the Laws of Malta.

${ }_{31}$ Canon 1381 paragraph 1 provides that 'the religious instruction of youth in schools of whatever kind is subject to the authority and inspection of the Church. In terms of paragraph 3, Ordinaries of places have also the right to approve teachers and textbooks of religion and also to demand in the interest of religion and morality that either teachers or books be removed'. See T. L. Bouscaren, A. C. Ellis, Canon Law: A Text and Commentary, op. cit., supra, note 421 , p. 747.

${ }_{32}$ The Constitution of Malta, section 40(2) provides as follows: 'No person shall be required to receive instruction in religion or to show knowledge or proficiency in religion if, in the case of a person who has not attained the age of sixteen years, objection to such requirement is made by the person who according to law has authority over him and, in any other case, if the person so required objects thereto: provided that no such requirement shall be held to be inconsistent with or in contravention of this article to the extent that the knowledge of, or the proficiency or instruction in, religion is required for the teaching of such religion, or for admission to the priesthood or to a religious order, or for other religious purposes, and except so far as that requirement is shown not to be reasonably justifiable in a democratic society'. Those students who opt not to receive Catholic instruction are taught ethics. 
at the University of Malta. In terms of Schedule 3 to the Education Act, the Archbishop has to approve all the appointment of teachers at the Faculty of Theology. This is in line with Canon 812 of the Code of Canon Law of $19833^{33}$

The Criminal Code also considers as a criminal offence the obstruction of reli-

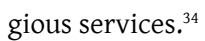

On the application of canon law to Malta, His Majesty's Court of Appeal confirmed on 20 December 1946 a judgment delivered by the Civil Court, First Hall, by Mr Justice A.V. Camilleri on 15 November 1946 in the names Lepre vs Agius et noe. Both judgments were to the effect that, in the absence of special laws, the canonical laws applied in Malta and had the force of law or of custom. In this respect, the 15 November 1946 judgment cites a string of judgments in support of this statement. ${ }^{35}$

Prior to the enactment of the Marriage Act, ${ }^{36}$ only Catholic marriages were regulated by custom. The Code of Canon Law regulated marriages in Malta and such regulation had over time crystallised into

33 Canon 812 of the 1917 Code of Canon Law reads as follows: 'Those who teach theological disciplines in any institutes of higher studies whatever must have a mandate from the competent ecclesiastical authority'. See New Commentary on the Code of Canon Law, op. cit., supra, note 421, pp. 966-971.

34 Chapter 9 of the Laws of Malta, section 165.

35 Arthur Bonnici asks the question whether Canon Law has any authority in Maltese jurisprudence. He replies that Sir Frederick Hankey, the Chief Secretary to Government 'asked the views of various renowned Maltese jurists on this matter. Judge Paul Debono answered that the provisions of Canon Law are referred to in cases not covered by the enactments of Civil Law. Judge Augustine Randon wrote that, if juridical opinions are founded on Canon Law, Court decisions are indirectly founded on such Law, considered as either as such, or as the Law of the custom of the land. Actually, in many cases, Judge Claudius V. Bonnici remarked, Canon Law served as a rule to H.M.'s Temporal Courts for their decisions. Judge Ignatius Bonavita opined that, when Civil and Roman Laws clash, Canon Law must be preferred, if the matter in question in any way concerns the spiritual, such as would be, for example, cases relating to marriage, and in the cases where the Civil Laws are silent. Judges John Vella and John Baptist Satarino admitted that in many cases Canon Law has to regulate the decisions of H.M.'s Temporal Courts. See A. Bonnici, History of the Church in Malta, op. cit., supra, note 399, p. 218. See also E. Mizzi, Malta in the Making 1962-1987: An Eyewitness Account, Malta 1995, pp. 219-238.

36 Chapter 255 of the Laws of Malta. 
a rule of customary law. Mixed marriages, whether celebrated in Malta or abroad, were not recognised by Maltese Law. ${ }^{37}$ This is because marriages celebrated by non-Catholic clergymen were not in accordance with the formalities prescribed by Canon Law. Maltese courts consequently declared them invalid on public policy grounds..$^{38}$ Marriage in Malta continues to be highly influenced by Canon Law even in the case of civil marriages. The Marriage Act recognises Catholic marriages as lawfully celebrated marriages and, in the case of civil marriages, applies several provisions thereto modelled on Canon Law, in particular the grounds of annulment of marriage. A departure from the above has been the Civil Unions Act, Chapter 530 of the Laws of Malta, which allows same sex partnerships which was enacted into law in 2014 as well as the 2017 amendments which allow a same-sex civil union to be converted into a same-sex civil marriage.

In so far as the written law is concerned, the relationship between Church and State is evident in various laws. It is not the purpose of this article to go through all the primary laws in Malta to identify where this relationship exists but an attempt will be made here to identify the most pertinent legislation:

(a) the Ecclesiastical Courts (Constitution and Jurisdiction) Law; ${ }^{39}$

(b) Anglican Church (Property) Ordinance; ;0

(c) Mortmain Act;

(d) Ecclesiastical Entities (Properties) Act; ${ }^{42}$ and

(e) General Elections Act, ${ }^{43}$ in so far as corrupt practices are concerned.

Agreements have been reached between the Church and the State on the transfer to the state of church immovable property not required

37 See A. Borg, The Question of Mixed Marriages in Malta, Msida 1969.

38 J. M. Ganado, Malta: A Microcosm of International Influences, in: Studies in Legal Systems: Mixed and Mixing, eds. E. Örücü, E. Attwooll, S. Coyle, The Hague 1996, pp. 234-235. See also Giorgio Lepre v. Avv. Dr Carmelo Agius et noe, Court of Appeal, 20 December 1946.

39 Chapter 1 of the Laws of Malta.

40 Chapter 19 of the Laws of Malta.

41 Chapter 201 of the Laws of Malta.

42 Chapter 358 of the Laws of Malta.

43 Chapter 354 of the Laws of Malta, Fourteenth Schedule, section 55, related to threatening to inflict undue spiritual influence. 
for pastoral purposes which is administered by the Joint Office in terms of the Ecclesiastical Entities (Properties) Act, church schools, the re-integration of the Faculty of Theology at the University of Malta and lately an agreement regarding the jurisdiction of the civil courts over Catholic marriages enacted into law through the Marriage (Amendment) Act, 2014 - Act No. XXI of 2014.

\subsection{Agreements with the Vatican}

A number of agreements have been concluded with the Vatican. These include:

(a) an Agreement entered into between the Holy See and Malta, signed on the 28th day of November 1991, relative to the transfer to the State of such immovable property in Malta as is not required by the Catholic Church for pastoral purposes and on the determination of certain issues pertaining to the relations between the Church and the State as regards matters of patrimony; which Agreement was done in two originals in the English and Italian language. The text of the said Agreement (without the annexes thereto) is reproduced in the Schedule to this Act. A copy of the Agreement, was laid on the Table of the House of Representatives on 29th November, 1991 and 25th May, 1992 (as to the annexes); ${ }^{44}$

(b) an Agreement between the Holy See and Malta on the Recognition of Civil Effects to Canonical Marriages and to the Decisions of the Ecclesiastical Authorities and Tribunals about the Same Marriages, as well as the Protocol of Application thereto, both signed in Malta on the 3rd February 1993; and

(c) a Third Additional Protocol thereto was signed in Malta on the 27th January 2014, which Agreement and protocols are reproduced in the Schedule to the Marriage (Amendment) Act, 2014. ${ }^{45}$

44 Ecclesiastical Entities (Properties) Act, Laws of Malta, Chapter 358.

45 Act No. XXI of 2014. 


\section{The Latest (2017) Attempt at Securalisation}

The latest legislative drafting conundrum proposed by government was the Marriage Act and other Laws (Amendment) Bill, Bill No. 1 of 2017, enacted into law through the Marriage Act and Other Laws (Amendment) Act, 2017, Act No. XXIII of 2017.

The long title of the Bill stated that it has as its purpose "the introduction of marriage equality'. This means that both heterosexual and homosexual couples, in their respective diversity, are to be treated equally in marriage. But is this really the case for the Act aims more at eliminating the characteristics common to heterosexual marriages rather than allowing for both legal regimes to co-exist harmoniously side by side with full respect to their own particularities.

Indeed, why was this Bill passed with such urgency through the House of Representatives in less than two weeks without allowing adequate discussion and reflection thereupon? The Bill was given a First reading in the House of Representatives on Saturday 24 June 2017. It was published the following Monday in the afternoon. Second reading begun to be debated on that very same day of publication when the public at large was not even aware of the contents of the Bill as no public consultation exercise took place beforehand as is customary with new legislation.

Bill No 1 was not intended to convert civil unions to civil marriages as one might have been led to believe. The Bill could have just easily contained a clause amending the Civil Unions Act whereby the word 'civil union' would have been substituted by 'marriage' together with a few other consequential amendments. That would have ensured that no controversy would have erupted and all the political parties in the House would have considered it as the implementation of an electoral pledge. But the Bill did more than that. It eliminated the characteristics of a heterosexual marriage which were nevertheless correctly retained by article 4 of the Civil Unions Act.

The government and opposition think that because they agree on the enactment of a particular law - whatever that may be and even if contained in their respective electoral programmes to the letter - then civil 
society should not have a role to comment thereupon. They consider themselves free to flesh out the contents of that electoral proposal without due public consultation. This is not quite the proper way of governing and both sides of the House are complicit therein as they think that once elected to the House democracy has no further purpose.

Like with other important laws, a consultation process should have been followed so that certain pitfalls which the Bill contained were ironed out before they reached the House. In this case it was not the Bill's principle which was controversial to the political parties, though the devil lied in the detail of the law.

Without a proper examination of the implications of the Bill's provisions taking place before the discussion in the House, the end result was that the law ended up being unconstitutional, and/or it breached human rights, and/or it created ambiguities and problems of interpretation. An examination of the Maltese Statute Book indicates that it is replete with examples of all of these kinds. So why add another example of bad drafting with all the attendant uncertainties it creates as Act No. XXIII of 2017 does?

In law one institute is distinguished from the other in order to set out the commonalities and differences between them. Once Parliament starts to mix institutes together, the end result is confusion par excellence. For instance, it is clear what is a religious marriage and a civil marriage in terms of the Marriage Act, and a civil union in terms of the Civil Unions Act for same-sex couples. It is also clear what is a cohabitation relationship in the Cohabitation Act. But what is the difference between a civil union and a same-sex marriage?

There has to be such a distinction once the two regimes are being allowed to co-exist side by side but the new law does not set out the distinction/s as clearly as one would wish it to do and as Maltese Law does in other civil law institutes, for instance, between filiation and adoption; emphyteusis and lease; use and habitation; testate succession and intestate succession; torts and quasi-torts; community of acquests and the separation of property between spouses, etc.

Moreover the Civil Unions Act, as enacted, was already a hybrid in its own right for it allows the formation of a civil union between two 
persons of the same sex or of different sex. So a heterosexual couple can also opt for a civil union instead of a marriage or cohabitation.

Is the new law an 'upgrade' of a civil union to a marriage? This does not appear to be the case for otherwise the Civil Unions Act would have been repealed and civil unions would have inextricably come to an end. The position is that the new law will allow both a homosexual marriage and a homosexual civil union in the same way that the law allows a heterosexual marriage under the Marriage Act and a heterosexual civil union under the Civil Unions Act, though it is not clear what the distinction is here. What is the difference between the two legal regimes of a homosexual marriage and a homosexual civil union? Once the new law allows a civil union to be converted into a same-sex marriage, what are exactly the benefits to be derived to the same-sex couple by going for this option?

The new law as drafted contains several drafting mistakes. One of the defects of the new law is that it removes from the Laws of Malta all reference to 'mother' in order to introduce gender neutral terminology which will supposedly ensure an equal treatment to heterosexual and homosexual marriages. However, there are certain instances where the law cannot but not use this term, otherwise it would end up being meaningless. Mothers and fathers, and wives and husbands, cannot be banned from mention in the law simply because they are atypical to a same-sex relationship which is after all the exception not the norm in society.

When drafting legislation one should ensure legal certainty, a human right in itself. But the new law throws away legal certainty in the rubbish bin. There should be nothing criminal, immoral, disrespectful or mischievous in referring to a woman who bears children as a mother and a man who has participated in the procreation of a child as a father. Otherwise, equality is being used only as a pretext to sacrifice diversity rather than celebrating it. What is ontologically different by definition cannot be rendered the same through a legal fiction. On the other hand, a marriage law of this nature should proclaim diversity in marriage rather than suppress the terminology used in a heterosexual marriage for, in so far as a heterosexual marriage is concerned, it should continue to use the terminology appropriate to it whilst new terminology should 
be introduced (as the law did when it introduced the Civil Unions Act and the Cohabitation Act) to cater for new circumstances which may develop in society (although in the case of Act No XXIII of 2017 it is the law which is developing society not the other way round).

The worst amendment is that to the Interpretation Act, Chapter 249 of the Laws of Malta, where in all the laws of Malta, 'the word father shall include mother; the word mother shall include father'. This means that if the legislator wanted to assign a particular right or duty to a mother or a father in a heterosexual marriage, this is no longer possible for that duty has to be carried out by both spouses indiscriminately. Is this not an interference with the right to respect for family life in so far as a heterosexual marriage is concerned? It is a case where equality cannot be achieved because one is dealing with two diverse legal regimes. Thus, if the ministry of health proposes to Parliament a law that new born babies should be breast feed by their mother, then according to the amendment proposed by Act No. XXIII of 2017 to the Interpretation Act, that duty is also imposed on the father even if by the law of nature - not by the law of the Maltese Parliament - fathers can never breast feed! Is it a case of taking equality for unequal things too far and in turn adopting unreasonable measures which are not in themselves proportional?

The Marriage Act was also amended so as not to distinguish any longer between a brother and a sister by substituting those words with the undefined word 'sibling', a term used in the Civil Code only in the context of adoption where it is ascribed a technical meaning. Again, whilst we know who is a brother and a sister within a Maltese Law context and whilst this terminology is well understood today, Act No. XXIII of 2017 introduced a term (sibling) which nobody really knows what it really means as it is relatively alien to the Maltese legal system and will presumably differ from that currently in use. This naturally leads to confusion because one and the same word should be given only one uniform meaning in the same law; otherwise the person reading the law gets confused and legal certainty is thrown overboard.

The only amendment made by Act No. XXIII of 2017 to the Civil Unions Act was to allow a civil union to be converted into a marriage. Now why would a same-sex couple want to convert such union into a marriage? 
Or, better, what are the advantages of a homosexual marriage to a homosexual civil union? Act No. XXIII of 2017 is silent in this respect. The very recently published subsidiary law entitled 'Conversion of Civil Unions into Marriage Regulations, 2017'46 does not contribute at all to provide clarity as to this distinction. Again, legal uncertainty abounds.

When Act No. XXIII of 2017 allows changes to surnames of spouses, it does so prospectively. But is this provision not discriminatory from a human rights perspective - both under the Constitution and the European Convention on Human Rights - in relation to heterosexual couples married before the entry into force of Act No. XXIII of 2017? The 1993 amendments to the Civil Code did not perpetuate such discriminatory practice.

Political parties believe that electoral pledges have to be respected once in power. But there are ways and means how these pledges can be implemented. By enacting laws which run counter to human rights (discrimination, privacy and legal certainty), the rule of law, go beyond reasonable proportion and strike at the heart of societal diversity and coexistence is surely not the best way forward as the law should act as a unifying not as a dividing force whilst still ensuring that same-sex couples enjoy the right to marriage.

It is one thing to implement them by using clear and unambiguous legal drafting and it is totally another thing to be disrespectful towards heterosexual couples whilst at the same time being a source of misinformation to same-sex couples. As the Polish Constitutional Tribunal once held:

The principle of the rule of law requires the legislature to ensure that all adopted legislative acts comply with the standards of good legal drafting, jointly referred to in the Polish doctrine as the principle of appropriate legislation. It is functionally tied to the substantive principles of legal certainty, legal security and protection of trust in the State and its laws. All enacted provisions must be precise and comprehensible to their addressees, without raising doubts as to the scope of duties imposed or rights granted thereby.

46 Legal Notice 382 of 2017 published in "The Malta Government Gazette" on 22 December 2017. 
Admittedly, the drafters of Act No. XXIII of 2017 have failed miserably in this respect.

\section{Conclusion: Inroads in Church and State Relations in Malta}

State-Church relations in Malta cannot be said to have been without difficulty. The State did have its share of feuds with the Catholic Church. Two such hostilities occurred in the last century, the first was between the Progressive Constitutional Party headed by Lord Gerald Strickland and the Church and the second between the Malta Labour Party led by Dom Mintoff and the Church led by Mgr. Sir Michael Gonzi. ${ }^{47}$ Two other hostilities related to Church schools ${ }^{48}$ and Church property. ${ }^{49}$

Inroads to the relationship between Church and State are however developing in the direction of emphasising more the lay component of the state rather than the Catholic component of the state. This is due to the fact that the Catholic faith in Malta is on the decline and that Maltese are questioning the teachings of the magisterium especially in areas related to divorce, same sex unions, assisted suicide, surrogacy and other morally related issues. Recently divorce was introduced following a positive outcome in a referendum and then through a law amending the Civil Code, the enactment of legislation allowing transsexuals to marry (this being a type of same-sex marriage), and the introduction of a Civil Unions Act which not only allows gay and lesbian marriages but also adoption of children by such couples. ${ }^{50}$ The morning after pill was

${ }^{47}$ See Ch. Buttigieg, Mikiel Gonzi: Hamsin Sena fit-Tmum (Translation: Michael Gonzi: 50 Years a Leader), Klabb Kotba Maltin, 2015, pp. 5-6 and pp. 69-80; and A. Bonnici, History of the Church in Malta, op. cit., supra, note 399, pp. 266-277. See also D. Mintoff, Priests and Politics in Malta: A Brief Analysis, in: Mintoff: il-bniedem u l-istorja, ed. M. Cutajar (Translation: Mintoff: the Man and History), Pubblikazzjonijiet SKS 2012, pp. 246-252; and C. Catania, Strickland, Britain and the Vatican 1929-1932, Hamrun 2011, pp. 41-62.

48 See Fr D. Scerri O.P., The Saga of the Church Schools in Malta (1970-1986): A Historical Portrayal of Events, Valletta 2000.

49 See E. Mizzi, Malta in the Making 1962-1987..., op. cit., supra, note 428, pp. 389-427.

50 See J. Ellul O.P., The Catholic Identity of Malta after Ten Years of Membership in the European Union: Challenges and Prospects, "Reflections on a Decade of EU Membership: Expectations, 
also allowed to be imported and used in Malta. Pressure is currently being put on the Maltese government to start debating the law totally prohibiting abortion in Malta.

The Catholic values which were very strong in Malta in the past are being eroded and Malta is evidencing a trend towards the secularisation of the state. Government is also proposing the revision of the Embryo Protection Act though, at the moment of writing, no Bill has been published encapsulating Government's proposals for legislative change. ${ }^{51}$ Government has also enacted a law to allow same sex couples to marry as well even though civil unions are, for all intents and purposes of law, equivalent to marriage. As a matter of fact, section 4(1) of the Civil Unions Act provides that: 'Save as provided in this Act a civil union, once registered, shall mutatis mutandis have the corresponding effects and consequences in law of civil marriage contracted under this Act'. Finally, government has also published a subsidiary law, the Leave for Medically Assisted Procreation National Standard Order, 2017 (Legal Notice 156 of 2017) which goes beyond the definition of 'prospective parents' in the Embryo Protection Act, Chapter 524 of the Laws of Malta, which allows same-sex couples to seek in vitro fertilisation abroad and is assisted to do so through the granting of one hundred hours of leave with full pay even if the legal notice goes beyond Parliament's will in the Embryo Protection Act which limits IVF only to a heterosexual couple, whether married or cohabitating. This apart from the fact that abroad medically assisted procreation might not only include IVF as offered in Malta in terms of the Embryo Protection Act but also other forms of medically assisted procreation such as surrogacy, embryo freezing and gamete donation which gone beyond the limited form of medically assisted prorecation as contemplated in the said enactment.

The onslaught on the Catholic religion is no longer rabid as it used to be during last century when the two politico-religious confrontations

Reflections, Achievements, Disappointments, The Future”. Occasional Paper 02/2004, Institute for European Studies, University of Malta, Msida 2014; E. Agius, Co-operation in Marriage-Related Legislation, "Melita Theologica" Vol. 65, No. 2, 2015, pp. 27-51.

51 Conferentia Episcopalis Melitensis, Legislation Regulating Assisted Human Procreation: A Position Paper, Archbishop's Curia, Floriana, November 2015. 
took place. Yet, though still disharmonious, the relations between Church and State do not shock the population as they used to do in the past. This can be attributed to the stances taken by the three key players in this field: government, the population and the bishops. Politicians of all different ideologies are moving in the populist direction whilst embracing a more liberal ethic. The population has become more lax in the observance of Catholic values which inspired past generations, becoming more inbued with moral relativism, whilst the Bishops - though they still continue to teach what is good and what is bad - have to stand up to part of society's aversion to such teaching. This is a process which Western Europe has gone through and which globalisation and europeanization is bringing to the shores of the Maltese islands. 


\section{Summary}

\section{Church and State Relations in the Constitution of Malta}

This paper discussed the relationship between the Catholic Church and the State of Malta as evidenced primarily in the Constitution of Malta and secondarily in other Constitutional Laws. It is noted that the Roman Catholic Apostolic Religion is the national religion of Malta. Malta is a confessional state which respects freedom of conscious and worship and all other religions and cults are protected by law. It considers other instances, such as the instructions of children in state schools in the Catholic religion and the influence of the Catholic Church on the state. However, lately, the relationship between the Church and the State has suffered as the state is becoming more liberal in orientation as evidenced by the enactment of laws which do not comply with the Catholic teaching of the Church's magisterium. Hence, this opens different challenges to the Catholic Church in Malta not hitherto known to it.

Keywords: Church-State relations, Malta, freedom of conscience and worship, Canon Law influences on Maltese Law

\section{Relacje Kościoła i państwa w konstytucji Malty}

Artykuł omawia związek między Kościołem katolickim a państwem maltańskim, który regulują przede wszystkim Konstytucja Malty, a także inne ustawy państwowe. Należy zauważyć, że religia rzymskokatolicka jest religią państwową Malty. Malta jest państwem wyznaniowym, które szanuje wolność wyznania i kultu, a wszystkie religie są prawnie chronione. Artykuł analizuje przypadki, takie jak religijna formacja dzieci w szkołach państwowych i wpływ Kościoła katolickiego na państwo. Zdaniem autora, ostatnio stosunki między Kościołem a państwem stały się nieco napięte, gdyż państwo staje się bardziej liberalne, czego dowodem jest uchwalenie praw, które nie są zgodne z katolickim nauczaniem magisterium Kościoła. Stąd otwierają się różne wyzwania przed Kościołem katolickim na Malcie, dotychczas nie znane.

Słowa kluczowe: Relacje między Kościołem i Państwem, Malta, Wolność sumienia i wyznania, Wpływ prawa kanonicznego na prawo maltańskie

\section{Bibliography}

Agius E., Co-operation in Marriage-Related Legislation, "Melita Theologica" Vol. 65, No. 2, 2015, pp. 27-51.

Anon, The Jerusalem Bible, London 1966. 
Aquilina K. Religion needs protection, “The Times of Malta” 22 July, 2015, p. 22.

Aquilina K. Guardian of the Constitution, "The Times of Malta" 28 September 2015, p. 16.

Aquilina K. Retain vilification law, "The Times of Malta” 6 October 2015, p. 14.

Archdiocese of Malta, Position paper on the Decriminalisation of the Public Vilification of Religion and Pornography, Conferentia Episcopalis Meliensis, Floriana 7 August 2015.

Basile F., A Cinque Anni della riforma dei reati in materia di religione: un commento teorico-pratico degli artt. 403, 404 e 405 c.p., in: Stato, Chiesa e pluralismo confessionale, May 2011, available at: www.statochiesa.it (28.11.2017).

Beal J. P., Coriden J. A., Green T. J., New Commentary on the Code of Canon Law, New York 2000.

Bonnici A., History of the Church in Malta, Vol. 3, Period 4 - 1800-1975, Zabbar 1975.

Borg A. The Question of Mixed Marriages in Malta, Msida 1969.

Bouscaren T. L., Ellis A. C., Canon Law: A Text and Commentary (third revised edition), Milwaukee 1957.

Buttigieg C., Mikiel Gonzi: Hamsin Sena fit-Tmum, Klabb Kotba Maltin 2015.

Catania C., Strickland, Britain and the Vatican 1929-1932, Hamrun 2011.

Conferentia Episcopalis Melitensis, Legislation Regulating Assisted Human Procreation: A Position Paper, Archbishop's Curia Floriana, November 2015.

DeGiorgio G. E., Church and State in Malta, "Scientia" Volume 14, Apr.-Jun. 1948, pp. 57-66 and Volume 14, Jul.-Sept. 1948, pp. 128-143.

Ellul O. P., Fr J. The Catholic Identity of Malta after Ten Years of Membership in the European Union: Challenges and Prospects, "Reflections on a Decade of EU Membership: Expectations, Reflections, Achievements, Disappointments, The Future". Occasional Paper 02/2004, Institute for European Studies, University of Malta, Msida 2014.

Ganado J. M., Malta: A Microcosm of International Influences, in: Studies in Legal Systems: Mixed and Mixing, eds. E. Örücü, E. Attwooll, S. Coyle, The Hague 1996, pp. 234-235.

Herrera J. A., Crimes Against the Religious Sentiment, LL.D. thesis, Faculty of Laws, University of Malta, Msida 1958.

House of Commons Parliamentary Papers, Papers Relating to the New Constitution of Malta, His Majesty's Stationery Office, London 1921 [1921], Cmd. 1321.

Mangion R., Aspects on forces of influence by persons and groups under Malta's first responsible government, in: The Quest for Authenticity and Human Dignity, Melita Theologica, eds. E. Agius, H. Scerri, Msida 2015 (Supplementary Series, 6).

Mercieca Sir A., Stato e Chiesa in Malta: Nomina dei Vescovi, "Archivio Storico di Malta" Volume 7, 1935-1936, pp. 87-92.

Micallef D., 1921 A Landmark in Maltese Political History, Msida 1978.

Micallef D., 1921: Electoral Issues, "Hyphen - A Journal published by the Lyceum" Vol. II, No. 4, 1980, pp. 158-168.

Mintoff D., Priests and Politics in Malta: A Brief Analysis, in: Mintoff: il-bniedem u l-istorja, ed. M. Cutajar, Pubblikazzjonijiet SKS 2012, pp. 246-252.

Mizzi E., Malta in the Making 1962-1987: An Eyewitness Account, Malta 1995. 
Refalo I., Constitutional Change in Malta, in: Office of the President, The President's Forum: Does Malta's Constitution Still Cater for the People's Needs, Valletta 2013, p. 74.

Robinson, O. F., Fergus, T. D., and Gordon, W. M. European Legal History, second edition, London 1994.

Scerri O. P. Fr. D., The Saga of the Church Schools in Malta (1970-1986): A Historical Portrayal of Events, Valletta 2000.

Scicluna C. J., Religion and the 1921 Constitution: Genesis and Implications, Licentiate in Sacred Theology, Faculty of Theology, University of Malta, Rabat, October 1988. 